\title{
ADAPTATION OF ELEMENTS OF SUDAN GRASS CULTIVATION TECHNOLOGY TO THE CONDITIONS OF DRY-STEPPE ZONE
}

\author{
Beybit NASIYEV ${ }^{*}$, Nurbolat ZHANATALAPOV ${ }^{1}$, Vladimir SHIBAIKIN ${ }^{2}$, HRistina YANCHEVA \\ ${ }^{1}$ Zhangir khan West Kazakhstan Agrarian - Technical University, Republic of Kazakhstan \\ ${ }^{2}$ Saratov State Vavilov Agrarian University, Russia \\ ${ }^{3}$ Agrarian University Plovdiv, Republic of Bulgaria \\ *Corresponding author: veivit.66@mail.ru
}

Received: 26.01 .2020

\begin{abstract}
Sudan grass (Sorghum sudanense (Piper.) Stapf) for the dry-steppe zone of West Kazakhstan is the most productive and drought-resistant, as well as promising culture. Therefore, in order to ensure the smooth supply of feed to livestock, it is important to carry out studies on the adaptation of elements of Sudan grass cultivation technology to the regional conditions. The research examined different sowing times at 10-day intervals, and for the harvesting of green fodder, haylage and hay, the harvesting times were examined in different phases of development, as well as grazing mode of use of Sudan grass. The results of scientific research showed that for the conditions of the region it is important to select both optimal sowing and harvesting times. In the years of research, the yield of dry mass of Sudan grass at different sowing times was 21.05-23.37 $\mathrm{c} / \mathrm{ha}$, with the highest productivity determined at 1 early sowing time. When studying the time of harvesting, high yield of dry mass of Sudan grass was ensured during harvesting of plant formations in the blooming period 19.06-23.69 $\mathrm{c} / \mathrm{ha}$. Under grazing conditions in the study area, Sudan grass produced 16.99 c/ha of dry mass in a total of 4 browsing.
\end{abstract}

Key words: feed value, grazing regime, harvesting period, productivity, sowing period

\section{INTRODUCTION}

The most important link in establishing a sustainable feed base in West Kazakhstan is the mandatory cultivation of drought-resistant crops. Sudan grass - Sorghum sudanense (Piper.) Stapf is among this group of cultures. In dry weather conditions, it provides crop stability compared to traditional feed crops, is able to grow rapidly after mowing and can be used for silage, haylage, herbal flour and green mass (Andreev, 1989).

This culture is characterized by high yields, rapid growth and drought resistance (Fribourg, 1995; Cole et al., 1996; Basaran et al., 2017). Sudan grass yield is particularly high during periods of moisture stock abundance (Habyarimana et al., 2004). Sudan grass, along with drought resistance, has good ability to carry salinization of soil (Sliwinski and Brzóska, 2008). Smaller leaf area, secondary roots and vegetable wax on the surface makes Sudan grass more drought resistant (Sarrantonio, 1994). Another advantage of this culture is that it grows faster and thus are more competitive and suppress the growth of weeds (Clark, 2007). This culture makes good use of precipitation in the second half of summer, thereby forming a large above-ground mass. Sudan grass is characterized by good aftermathability, tilling capacity, in daily increase exceeds corn, and good aftermathability allows to obtain 3-4 mowings (Nasiyev et al., 2019). In terms of nutritional value it also occupies one of the leading places. In $1 \mathrm{~kg}$ of green mass there are 0.22 fodder units and up to 20 grams of digestable protein. In terms of nutrient content, Sudan grass is superior to many other cereal herbs and contains less fiber (Shatilov, 1981)

Sudan grass is a popular culture for the production of full-fledged fodders in Europe and Asia (Spaar and Schuhmann, 2000; Uzun et al., 2009; Nazli et al., 2014; McIntosh, 2016; Blanco, 2016; Amaducci and Colauzzi, 2016).

All the above-mentioned advantages of Sudan grass depend on the correct selection of sowing terms and harvesting times. Sudan grass belongs to late-sowing crops. Planting of Sudan grass is better carried out when warming the soil at the depth of $10 \mathrm{~cm}$ up to $10-12{ }^{\circ} \mathrm{C}$. In case of early sowing in insufficiently heated soil, field germination of seed material decreases to 40 percent, the number of dead seeds increases sharply, the period of germination of survivors increases to 20-25 days, and seedlings are obtained thinned. At the same time, it is not recommended to be late with the sowing of Sudan grass, as in this case the seeds enter already dry soil, which also 
delays their germination (Bondarenko and Kopyrin, 1985; Zherukov et al., 2006; Kapustin, 2019)

An important point is the choice of sowing term. Seeds begin to germinate at soil temperature at the depth of their coverage $5-8^{\circ} \mathrm{C}$. However, the optimal temperature for seed germination is $10-12^{\circ} \mathrm{C}$. During cultivation for fodder purposes there is an experience in sowing Sudan grass at soil temperature $8-10{ }^{\circ} \mathrm{C}$ at the depth of seedingdown (Kshnyakin and Zozulin, 1984; Oten, 2017; Lukmanova, 2019).

In agricultural practices of Sudan grass, it is also important to harvest at the optimal time. According to some scientists, harvesting of Sudan grass for green food and hay is recommended to be carried out in stemextention stage (Puchkov, 1974), according to others - in heading phase (Zavarzin et al., 2002). It should also be taken into account that the time of the first mowing has a significant effect on the harvest value. When mowing during stem-extention stage, the first mowing is lower than in ear emergence phase, but the largest harvest is formed (Nasiyev et al., 2019). Kolomiec et al. (1999) recommend taking into account grade characteristics of Sudan grass when selecting harvesting time, noting that Sudan grass must be harvested before or at the beginning of ear formation.

Due to the distance, Sudan grass is also a promising crop for use in grazing mode. When growing in grazing mode, the time of phenological phases beginning and length of growing period are of great practical importance, as these indicators determine the time of economic use. Grigoriev (1963) found a lack of photoperiodic induction in various grades of Sudan grass, which allows to regulate the time of plants to achieve suitability for economic use in a specific soil-climatic zone.

Despite all the noted advantages, sowing areas of Sudan grass in the dry-steppe zone of West Kazakhstan region to date are insignificant and its yield remains very low. The main reason is the lack of adaptive technologies for its cultivation. Due to the lack of research in these areas, the aim is to increase the yield of Sudan grass by selecting more optimal sowing and harvesting times, as well as to study Sudan grass in grazing mode for the uninterrupted supply of livestock with full-fledged feed.

\section{MATERIALS AND METHODS}

Three field experiments were conducted in 2018-2019 on the base of the experimental permanent study area of the Zhangir Khan West Kazakhstan Agrarian-andTechnical University (the Republic of Kazakhstan, Uralsk).

Soil of the experimental area is characteristic for drysteppe zone of West Kazakhstan. The area of divisions is $50 \mathrm{~m}^{2}$, repetition - threefold, location of divisions is random.

Test of the 1 to study the timing of sowing in total, taking into account 3 repeats, included 9 plots. The length of each plot is $10 \mathrm{~m}$ and width is $5 \mathrm{~m}$. Additionally, there are protective plots with a length of $2 \mathrm{~m}$ and width of $5 \mathrm{~m}$.

Test 2 on the study of harvesting terms also consisted of 9 plots with a length of $10 \mathrm{~m}$ and width of $5 \mathrm{~m}$. Additionally, there are protective plots with a length of 2 $\mathrm{m}$ and width of 5 . Additionally there are protective divisions with length of $2 \mathrm{~m}$ and width of $5 \mathrm{~m}$.

Test 3 in the study of sudan grass grazing regime was carried out in the plots with dimensions of $20 \mathrm{~m}$ long, 10 $\mathrm{m}$ wide in 3 repeats. Additionally there are protective divisions with length of $2 \mathrm{~m}$ and width of 5 .

The distance between each test area is $10 \mathrm{~m}$. The test patterns met the requirements of the current procedure.

In the first experiment, 3 terms of sowing of Sudan grass were studied. 1 - sowing at the soil temperature at the depth of seeding-down $8-10^{\circ} \mathrm{C} ; 2$ - sowing in 10 days after 1 term; 3 - sowing in 10 days after 2 terms.. Terms of Sudan grass planting: in 2018 - 1 term - April 29, 2 term - May 9, 3 term - May 19. In 2019 - 1 term - April 27, 2 term - May 7, 3 term - May 17.

In the second experiment, 3 terms of Sudan grass harvesting were studied: term 1 - before heading phase, term 2 - at the beginning of heading phase, term 3 - in blooming period. The third study examined the use of Sudan grass in grazing. Terms of sudan grass harvesting in the second test: 2018 - 1st term on June 17, 2nd term on June 23, 3rd term on June 28; 2019 - 1st term on June 9, 2nd term on June 14, 3rd term on June 25.

When using Sudan grass in grazing mode, the first browsing of plant formations was carried out by simulating in the interval of tillering phases - stem elongation. In the future, repeated browsing of of Sudan grass plant formations was carried out as the grazing vegeative mass grew to the height of $40-50 \mathrm{~cm}$. The yield of grazing phytocenosis was determined by the cut-sample method. For this purpose, areas with characteristic plant cover were selected. Selection of plant samples was carried out in 3-4-fold repetition. The size of the accounting site was $1 \mathrm{~m}^{2}$. Vegetation was cut close to the soil and folded in a bundle, supplying a label. Then, the weight of the green mass of vegetation was determined on the scales, and then the yield in hectares was calculated by the conversion.

A zoned variety of Sudan grass - Brodskaya 2 was used in the experiment. During the study of Sudan grass, the technology of its cultivation adopted in the West Kazakhstan region was applied. In the progress of the experiments, mineral fertilizers were used in doses recommended for the West Kazakhstan region: Nitrogen (20 kg N/ha), Phosphorus (60 kg P/ha). In cultivation tests, sudan grass was studied without the use of irrigation (boharic land).

During field tests, accounting, monitoring of phenological phases and growth of Sudan grass were carried out according to generally accepted methods (Novoselov et al., 1987). The height of plants was 
measured in the phases of main development of Sudan grass: tillering, stem elongation, ear formation, blooming. Photosynthetic activity of Sudan grass crops was studied according to the generally accepted method (Nichiporovich, 1961). The definition of the main photosynthetic indicators was carried out by the development phases of sudan grass. The area of one leaves was calculated by the formula of Anikeev-Kutuzov: $\mathrm{LA}=2 / 3 \mathrm{p}^{*} \mathrm{~h}$, where: $\mathrm{p}$ - is the width of leaf, $\mathrm{cm} ; \mathrm{h}$ - is the length of leaf, $\mathrm{cm}$.

The foliage was determined by the weight method by determining the specific weight of leaves in the total green mass of sudane grass.

In the experiments, the green mass of Sudan grass was harvested using the continuous method with a mowing machine.

Based on the results of chemical analysis of green mass of Sudan grass, bioenergetic evaluation of the studied methods was carried out according to the accepted method (Novoselov et al., 1989). Statistical data processing, dispersion analysis, and construction of charts are performed using Statistica 6.0.

\section{RESULTS AND DISCUSSION}

\section{Morphological and biometric indicators of Sudan grass}

The growth and development of Sudan grass was significantly influenced by existing weather conditions of the growing period. According to weather conditions, the most favourable conditions for the growth and development of Sudan grass were in 2019. In June 2019, when there was intense growth and harvest formation of Sudan grass, $40.2 \mathrm{~mm}$ of precipitation fell, which is 9.2 $\mathrm{mm}$ more than the multi-year data. By contrast, $6.2 \mathrm{~mm}$ of rainfall fell in 2018 in June, $24.8 \mathrm{~mm}$ less from the norm. In addition, in 2018 there were not quite temperature favorable conditions. In June 2018, the average monthly air temperature was $0,6{ }^{\circ} \mathrm{C}$ lower than the norm and was $19,8^{\circ} \mathrm{C}$. Cool weather in June 2018 held back the growth and development of Sudan grass (Table1).

Table 1. Average monthly air temperature and rainfall during the growing season of Sudan grass 2018, 2019

\begin{tabular}{|c|c|c|c|}
\hline \multirow{2}{*}{ Years } & \multicolumn{2}{|c|}{ Months } & \multirow{2}{*}{ Average/sum } \\
\hline & May & June & \\
\hline \multicolumn{4}{|l|}{ Mean monthly temperature, ${ }^{0} \mathrm{C}$} \\
\hline 2018 & 17,8 & 19,8 & 18,8 \\
\hline 2019 & 18,3 & 22,2 & 20,3 \\
\hline Long-time average annual data for 10 years & 15,6 & 20,4 & 18,0 \\
\hline \multicolumn{4}{|l|}{ Sum of rainfall, MM } \\
\hline 2018 & 29,9 & 6,2 & 36,1 \\
\hline 2019 & 9,2 & 40,2 & 49,4 \\
\hline Long-time average annual data for 10 years & 27,0 & 31,0 & 58,0 \\
\hline
\end{tabular}

The current weather conditions had a significant impact on the height of plants. Higher plants were noted in 2019. On the options of sowing term, the height of plant formation of Sudan grass in 2019 was from 92.18 (term 3) to 103.50 (term 1). At the same time, the height of Sudan grass plants in the main phases of development depended on the weather conditions of vegetation period. According to the average data of the height of Sudan grass plants, the variants of sowing term for 2018 and 2019 show the nonlinear development of the process.
From the sowing time, the lowest growth of Sudan grass plants was determined on the option 3, i.e. 20 days after 1 sowing time. When studying the terms of harvesting, the height of plants in 2019 was 62.05 (1 term) - 98.92 (3 term) cm. However, in 2018 there was a decrease in plant growth in all options. At the same time in 2018, the lowest growth of Sudan grass $51.32 \mathrm{~cm}$ was noted on the option 1 of harvesting period before heading phase. 




Fugure 1. Effect of sowing and harvesting time by height of Sorghum sudanense on average for 2018, 2019, cm. Sowing terms: $1-$ sowing at the soil temperature at the depth of seeding-down $8-10^{\circ} \mathrm{C} ; 2$ - sowing in 10 days after 1 term; 3 - sowing in 10 days after 2 terms. Harvesting terms: 1 - before heading phase, 2 - at the beginning of heading phase, 3 - in blooming period.

As can be seen from Figure 1, when using early seeding (term 1), the highest height of plants is achieved, and when using version 1 of harvesting before heading phase - the smallest. Approximately the same height of Sudan grass plants is observed in the third option of harvesting and in the first option of sowing. With the tightening of Sudan grass seeding until the third term, the height of plants decreases, as well as with the delay of Sudan grass harvesting period until blooming period, the height of plants increases.

The productivity of any culture is formed not only by powerful vegetative mass, but also by morphobiological feature of the structure of individual organs. One of important components of Sudan grass yield is the degree of leaf formation and area of leaves (Grigoriev, 1963; Shatilov, 1981).

As statistical analysis in the studies showed, the area of leaves and leaf formation of Sudan grass were influenced both by sowing and time of harvesting. The scattering diagrams shown in Figure 2 for blocks A, B, C, $\mathrm{D}$ show the values for three variables at different sowing and harvesting times. By analyzing the diagrams by block, we determined the following relationships between these two variables. In block A, the following conclusions can be drawn that the decency at different harvesting times has a positive effect on the leaf area. And the efficiency on interaction depends on the terms of sowing. The best term of sowing in the ratio of leaf formation and dry mass collection is the first term of sowing. In block B there is the same relationship between the area of leaves and dry mass collection in terms of sowing terms as in block A. In block $\mathrm{C}$ we see a difference in the trend of the effect of harvesting times from the rest of the blocks. It can be seen from this diagram that the greatest effect of leaf formation is achieved at the third harvesting period. On block $\mathrm{D}$, we can suggest the greatest effect of leaf area on dry mass collection at the third harvesting term in blooming period of Sudan grass.

According to crop structure analysis data, sowing and harvesting times have a significant impact on the appearance of Sudan grass, which, as the most valuable part of the crop, determines the product quality (protein content and other nutritional components of a crop). In the research, the substantial leaf formation of Sudan grass was determined in 2019 compared to 2018.

On average for 2 years on the options of sowing term, high leaf formation $(25.98 \%)$ was determined at sowing term 1, at sowing at soil temperature at depth of seed filling $8-10^{\circ} \mathrm{C}$. The delay in seeding reduces the decency of Sudan grass to $20.04-23.65 \%$. On average for 2 years, the most optimal appearance of Sudan grass was formed when harvesting in earlier terms - before heading phase $(42.69 \%)$. If the harvesting time is delayed to the heading phase and blooming due to the increase of the share of stems and head in the crop structure, the number of leaves is reduced to $25.31-38.17 \%$. On average for 2 years in the studies, the largest area of leaves of Sudan grass 15.44 thousand $\mathrm{m}^{3} / \mathrm{ha}$ is set on the option 1 of the sowing term. Of the harvesting time, the highest values in the area of leaves were noted when harvesting Sudan grass in blooming period -13.18 thousand $\mathrm{m}^{2} /$ ha. Delaying both sowing and harvesting times reduces the area of Sudan grass leaves. 

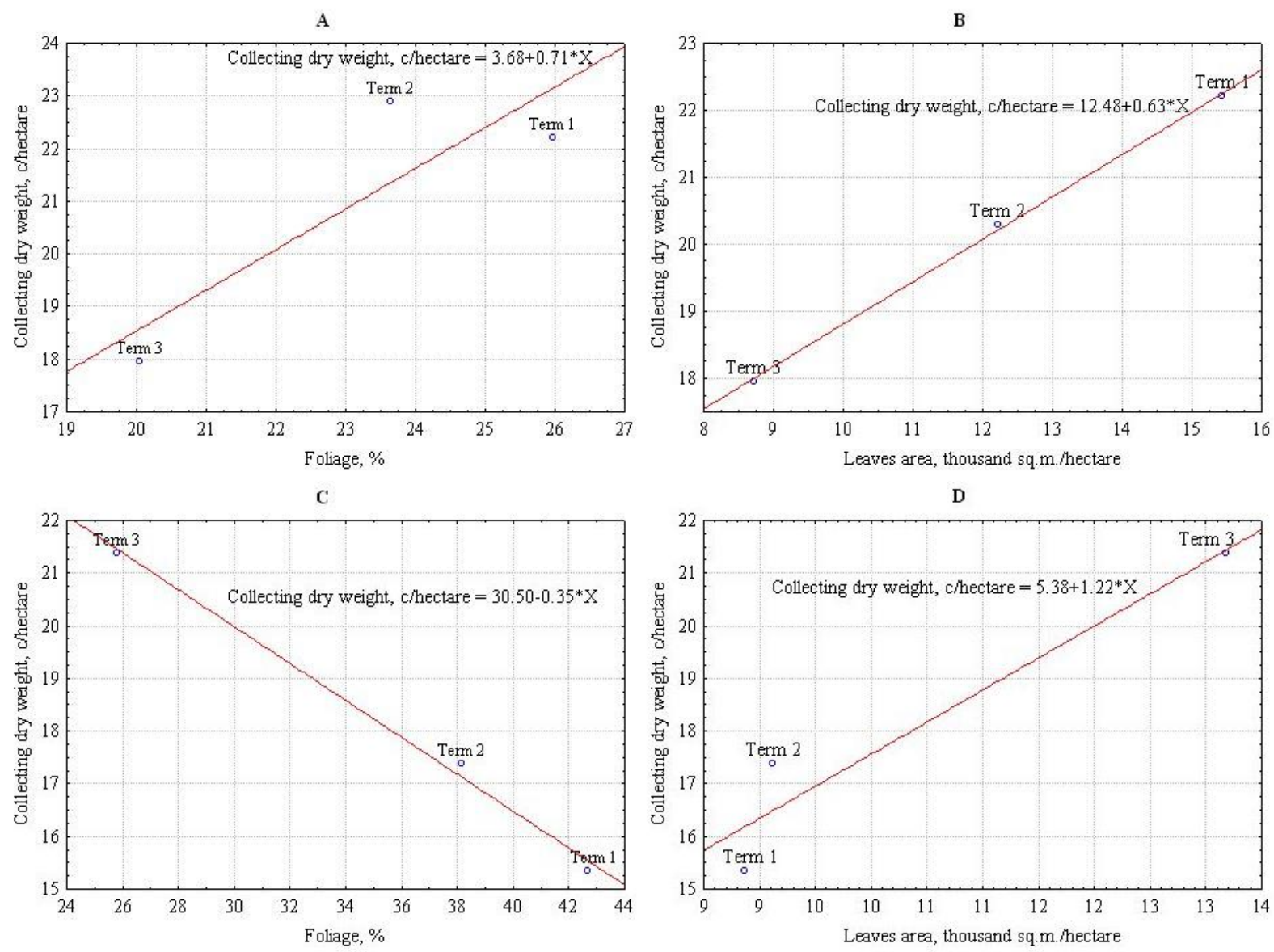

Fugure 2. Influence of leaf formation and area on the collection of dry mass of Sorghum sudanense at different time of sowing and harvesting, average for 2018, 2019: A - foliage at different sowing time; B - leaves area at different sowing time; C - foliage at different terms of harvesting; D - leaves area at different terms of harvesting

The degree of artisanal activity is also an important indicator of Sudan grass (Grigoriev, 1963; Shatilov, 1981). Research shows that sowing and harvesting times have a direct impact on tilling capacity indicators. On average for 2 years of the research, the largest degree of tilling capacity activity (4.1) was determined at sowing term 1, and the smallest (3.75) - at the late third term. On the options for studying harvesting time there was determined a different degree of tilling capacity activity of Sudan grass. During harvesting before heading phase, tilling capacity of Sudan grass was 3.75. When harvesting at the beginning of heading phase, the number of Sudan grass scions is 3.85 pieces per plant. With further delays in the harvesting period until blooming period, the number of Sudan grass scions increased to 3.95 pcs per 1 plant (Table 2).

Table 2. Biometric indicators of growth and development of Sudanese grass depending on adaptive cultivation technologies for 2018, 2019

\begin{tabular}{|c|c|c|c|c|c|c|c|}
\hline Sowing time & $\begin{array}{c}\text { Number of } \\
\text { scions, } \\
\text { pcs per } 1 \\
\text { plant } \\
\end{array}$ & $\begin{array}{c}\text { Leaves } \\
\text { area, } \\
\text { thousand } \\
\text { m }^{2} / \mathrm{ha}\end{array}$ & $\begin{array}{c}\text { Foliage, } \\
\%\end{array}$ & Harvesting time & $\begin{array}{l}\text { Number of } \\
\text { scions, } \\
\text { pcs per } 1 \\
\text { plant } \\
\end{array}$ & $\begin{array}{c}\text { Leaves } \\
\text { area, } \\
\text { thousand } \\
\text { m }^{2} / \mathrm{ha} \\
\end{array}$ & $\begin{array}{c}\text { Foliage, } \\
\%\end{array}$ \\
\hline $\begin{array}{l}1-\text { sowing at the soil } \\
\text { temperature at the depth } \\
\text { of seeding-down } 8-10^{\circ} \mathrm{C}\end{array}$ & 4.1 & 15.44 & 25.98 & $\begin{array}{l}1 \text { - before heading } \\
\text { phase }\end{array}$ & 3.75 & 8.8 & 42.69 \\
\hline $\begin{array}{l}2 \text { - sowing in } 10 \text { days } \\
\text { after } 1 \text { term }\end{array}$ & 3.95 & $12 ., 2$ & 23.65 & $\begin{array}{c}2 \text { - at the } \\
\text { beginning of } \\
\text { heading phase }\end{array}$ & $3, .85$ & 9.12 & 38.17 \\
\hline $\begin{array}{l}3 \text { - sowing in } 10 \text { days } \\
\text { after } 2 \text { terms }\end{array}$ & 3.75 & 8.72 & 20.04 & $\begin{array}{l}3 \text { - in blooming } \\
\text { period }\end{array}$ & 3.95 & 13.18 & 25.31 \\
\hline
\end{tabular}




\section{Yield and feed value of Sudan grass}

Yield reflects and integrates all factors that affect the plant during its development, and its magnitude is always the result of a compromise between productivity and sustainability. According to Zhuchenko (1990), agronomic interpretation of plant adaptability implies such use of environmental resources and resistance to abiotic and biotic stresses, in which a high crop index and its quality indicators are ensured, and subsequently, minimal costs of assimilators to maintain consistency of plant metabolic processes.
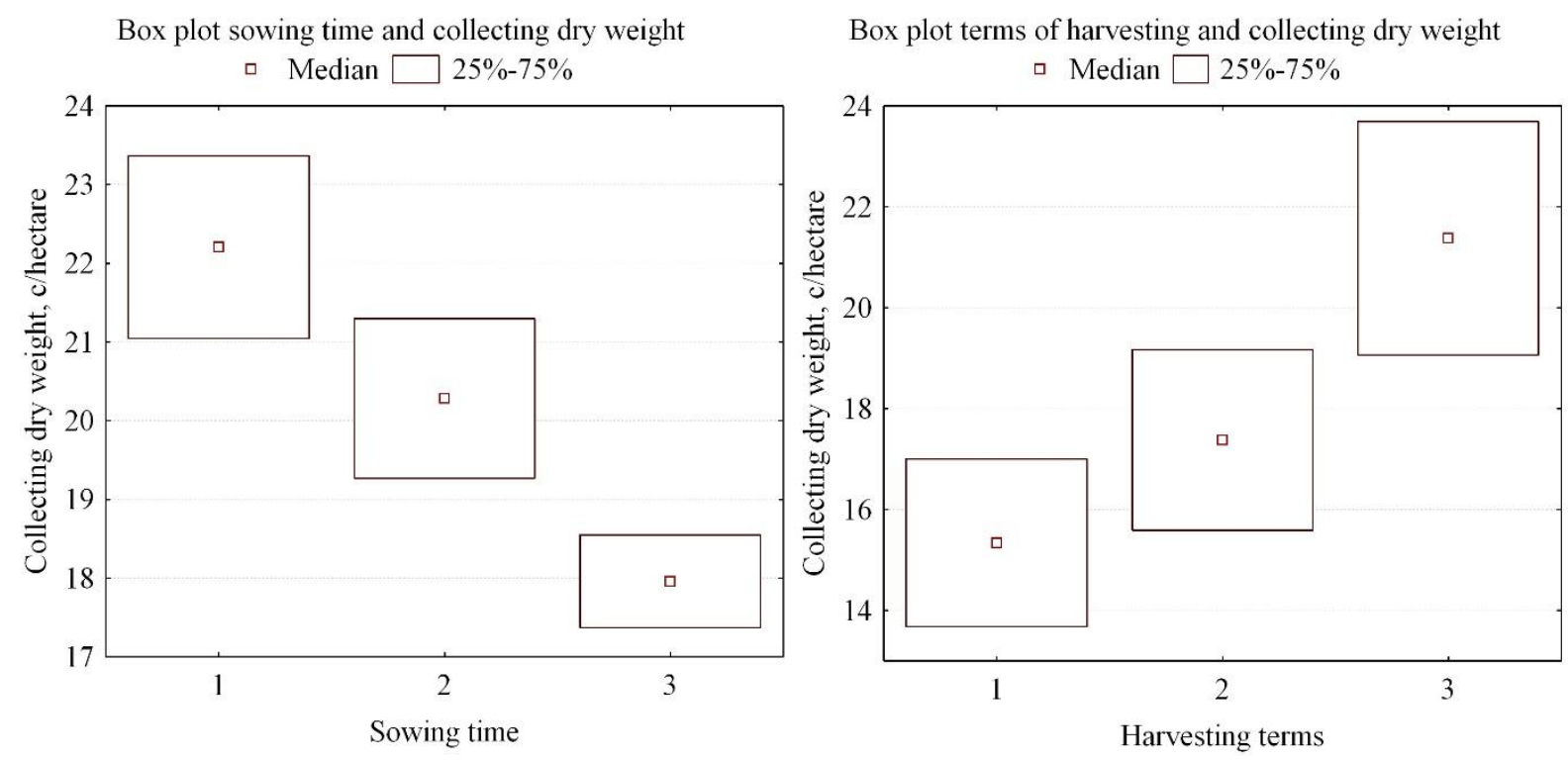

Fugure 3. Diagram of yield range of dry mass of Sorghum sudanense according to the options of sowing and harvesting time, c/ha (average for 2018, 2019)

As can be seen from Figure 3, on average for 2 years of research, the yield of dry mass of Sudan grass was significantly dependent on cultivation techniques: sowing and harvesting times. With Student criterion $=4.3$, the differences between arithmetic mean of the different levels are significant. The use of different sowing and harvesting times changes dry mass yield significantly. When studying the time of sowing and harvesting, the dry mass yield and collection of digestable protein were higher in 2019, compared to 2018. Higher productivity indicators on the option of sowing terms were determined at sowing in term 1 at soil temperature at seed filling depth $8-10^{\circ} \mathrm{C}$. On average for 2 years in this option, the yield of dry mass and collection of digestable protein were high at 22.06 and $1.66 \mathrm{c} / \mathrm{ha}$, respectively. Further delay in seeding by 10 and 20 days reliably reduces Sudan grass productivity. In the option of harvesting period, the most significantly high productivity of Sudan grass in terms of dry mass yield and collection of digestable protein differs in the harvesting period in blooming period of the given culture. On average for 2 years of harvesting in blooming period, the yield of dry mass at the yield of digestable protein of $1.46 \mathrm{c} / \mathrm{ha}$ was $21.50 \mathrm{c} / \mathrm{ha}$. With an earlier harvesting period before ear formation, the productivity of
Sudan grass is reliably reduced. A slight increase in the yield of digestable protein prior to the start of ear formation phase (1.43) compared to the start of ear formation phase (1.40) is due to the high content of protein in green mass of Sudan grass during early periods of development. It is known that with the further development of Sudan grass, there is a decrease in the content of protein in green mass.

The effect of year and cultivation techniques, including sowing and harvesting times, significantly affects the yield of exchange energy and collection of feed units of Sudan grass crops. Both on the output of exchange energy and on the collection of feed units, the productivity of Sudan grass was higher in 2019 compared to that of 2018. On average, during the years of research on the option of sowing terms, the largest yield of exchange energy (21.56 GJ/ha) and collection of feed units (19.39 $\mathrm{c} / \mathrm{ha})$ was observed at sowing term 1 at soil temperature at seed filling depth $8-10^{\circ} \mathrm{C}$. The delayed sowing period reduces the feeding value of Sudan grass. Thus, at the 3rd sowing term, the yield of exchange energy decreased to $17.51 \mathrm{GJ} / \mathrm{ha}$, and the collection of feed units - to $14.30 \mathrm{c} / \mathrm{ha}$. 
Table 3. Effect of sowing dates on the on the fodder value of Sudan grass in the dry steppe zone of Western Kazakhstan, 2018 , 2019

\begin{tabular}{|c|c|c|c|c|c|c|c|c|c|c|c|c|}
\hline \multirow{3}{*}{ Sowing terms* } & \multicolumn{6}{|c|}{ Exchange energy output. GJ/ha } & \multicolumn{6}{|c|}{ Harvesting of fodder units. c/ha } \\
\hline & \multicolumn{3}{|c|}{2018} & \multicolumn{3}{|c|}{2019} & \multicolumn{3}{|c|}{2018} & \multicolumn{3}{|c|}{2019} \\
\hline & $\mathbf{I}$ & II & III & $\mathbf{I}$ & II & III & $\mathbf{I}$ & II & III & I & II & III \\
\hline 1 & 20.96 & 19.83 & 20.92 & 24.16 & 22.19 & 21.27 & 18.79 & 17.86 & 18.85 & 21.70 & 19.97 & 19.14 \\
\hline 2 & 19.45 & 18.27 & 18.89 & 21.19 & 20.29 & 20.74 & 16.64 & 15.49 & 15.99 & 18.09 & 17.18 & 17.56 \\
\hline 3 & 16.56 & 17.63 & 16.81 & 18.70 & 17.15 & 18.18 & 16.47 & 15.49 & 15.99 & 15.40 & 14.00 & 14.70 \\
\hline $\mathrm{F}$ test & \multicolumn{6}{|c|}{$* * *$} & \multicolumn{6}{|c|}{$* * *$} \\
\hline
\end{tabular}

$* 1$ - sowing at the soil temperature at the depth of seeding-down $8-10^{\circ} \mathrm{C} ; 2$ - sowing in 10 days after 1 term; 3 - sowing in 10 days after 2 terms. $\mathrm{F}$ test of significance: $* * *$ - p-level<0.01; I, II, III - replicate experience.

Based on the data from Table 3, a single-factor dispersion analysis of dependence of exchange energy availability and feed units on sowing time was carried out. The significance test was calculated using Fisher's test. According to the test results, the influence of sowing terms on the content of exchange energy and on the content of feed units was confirmed (signal p-level < $0.01)$.
In the studies on adaptation of Sudan grass harvesting terms for the conditions of dry-steppe zone of West Kazakhstan according to the fodder value, the most accepted was the option of harvesting in blooming period. On average, for 2 years of study in this option, the yield of exchange energy and the collection of feed units on Sudan grass crops was the highest compared to the harvesting time in earlier phases, and these figures were $21.04 \mathrm{GJ} / \mathrm{ha}$ and $17.21 \mathrm{c} / \mathrm{ha}$, respectively.

Table 4. The impact of harvest time on the on the fodder value of Sudan grass in the dry steppe zone of Western Kazakhstan, 2018, 2019

\begin{tabular}{|c|c|c|c|c|c|c|c|c|c|c|c|c|}
\hline \multirow{3}{*}{ Harvesting terms* } & \multicolumn{6}{|c|}{ Exchange energy output. GJ/ha } & \multicolumn{6}{|c|}{ Harvesting of fodder units. c/ha } \\
\hline & \multicolumn{3}{|c|}{2018} & \multicolumn{3}{|c|}{2019} & \multicolumn{3}{|c|}{2018} & \multicolumn{3}{|c|}{2019} \\
\hline & I & II & III & $\mathbf{I}$ & II & III & I & II & III & I & II & III \\
\hline 1 & 14.99 & 13.81 & 13.74 & 18.31 & 17.14 & 17.32 & 12.56 & 11.60 & 11.54 & 15.58 & 14.41 & 14.56 \\
\hline 2 & 16.27 & 14.31 & 16.13 & 19.50 & 19.33 & 18.62 & 14.41 & 11.46 & 12.47 & 15.75 & 15.87 & 15.72 \\
\hline 3 & 19.38 & 18.00 & 18.57 & 23.31 & 23.77 & 23.21 & 15.79 & 14.71 & 15.25 & 18.88 & 19.45 & 19.15 \\
\hline F test & & & & & & & & & & & & \\
\hline
\end{tabular}

* 1 - before heading phase, 2 - at the beginning of heading phase, 3 - in blooming period.

F test of significance: $* * *-$ p-level $<0.01, *$ - p-level $<0.1$; I, II, III - replicate experience.

Based on the data from Table 4, a single-factor dispersion analysis of dependence of exchange energy availability and feed units on harvesting time was performed. When analyzing the exchange energy depending on harvesting time, F-test confirmed a significant difference between group averages with an error probability of less than $1 \%$. In the analysis of the effect of harvesting time on the content of fodder units, the difference essentiality between the average ones is tested at $10 \%$ level (signal p-level < 0.1 ). Consequently, the change of harvesting time has a significant effect on the amount of stored energy and the number of feed units.

\section{Grazing regime of Sudan grass use}

One of the distinctive characteristics of Sudan grass is the possibility of using this culture in grazing mode. Productivity in the use of Sudan grass in grazing mode is the main indicator of economic value and economic efficiency of this culture (Tyutyunnikov, 1973). In the studies in 2018, 2019, the yield of Sudan grass for the entire period of grazing regime of use depended on the yield of each browsing individually. On average for 2 years, the yield of green mass of Sudan grass used in grazing mode in browsing 1 was 29.70 c/ha with a dry mass collection of $4.74 \mathrm{c} / \mathrm{ha}$.In case of second alienation, the crop of the second sowing term was $29.76 \mathrm{c} / \mathrm{ha}$ of green mass and $5.13 \mathrm{c} / \mathrm{ha}$ of dry mass (Table 5). 
Table 5. Productivity and fodder value of Sorghum sudanense for pasture mode, average for 2018, 2019, c/ha

\begin{tabular}{|c|c|c|c|c|c|}
\hline \multirow{2}{*}{ Index } & \multicolumn{4}{|c|}{ Sequence of pasturing } & \multirow{2}{*}{ Amount of 4 pasturings } \\
\hline & 1 & 2 & 3 & 4 & \\
\hline Green mass, c/ha & 29.70 & 29.76 & 22.95 & 14.84 & 97.25 \\
\hline Dry mass, c/ha & 4.74 & 5.13 & 4.29 & 2.83 & 16.99 \\
\hline Fodder units, c/ha & 4.12 & 4.46 & 3.73 & 2.46 & 14.77 \\
\hline Digestible protein, c/ha & 0.52 & 0.53 & 0.44 & 0.26 & 1.75 \\
\hline Exchange energy, GJ/ha & 4.93 & 5.33 & 4.44 & 2.94 & 17.64 \\
\hline $\mathrm{LSD}_{05}$ & \multicolumn{4}{|c|}{ 2018: 0.34} & \\
\hline Dry mass, c/ha & \multicolumn{4}{|c|}{ 2019: 0.40} & \\
\hline
\end{tabular}

The harvest of the second browsing slightly exceeded the harvest of the first one. This confirms the influence of temperature factor on the growth intensity of grass. At the same time, stem of the second term of sowing by density was inferior to the first one; increase of green mass crop took place due to the increase of a plant mass. In the following, in browsings 3 and 4 there was showed a further decrease in productivity of Sudan grass. The yield of green mass in browsings 3 and 4 was 22.95 and 14.84 c/ha, respectively, with a dry mass collection of 4.29 and $2.83 \mathrm{c} / \mathrm{ha}$.

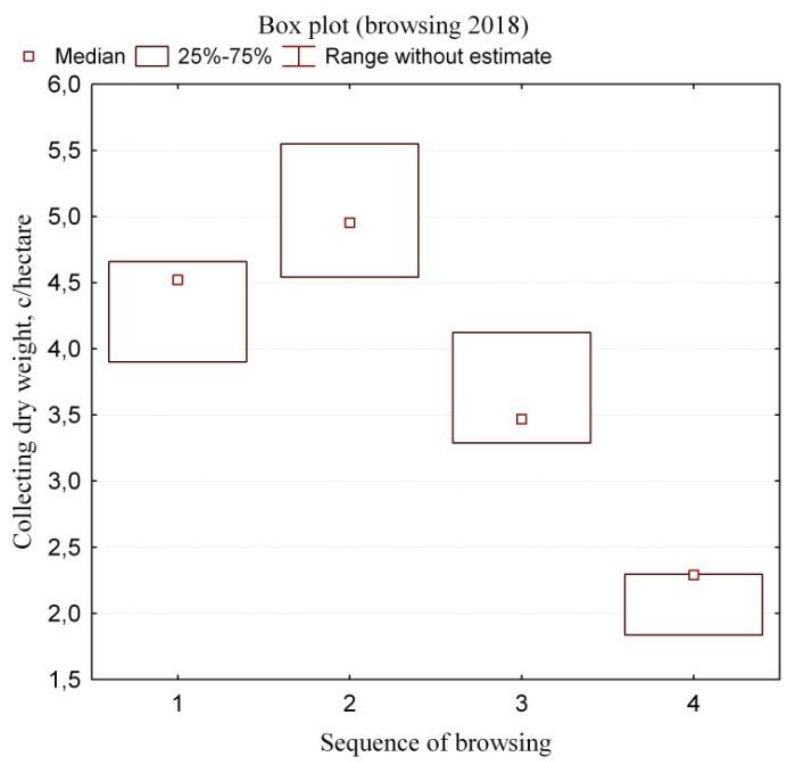

The total productivity of Sudan grass at grazing mode of use averaged $97.25 \mathrm{c} / \mathrm{ha}$ of green mass and $16.99 \mathrm{c} / \mathrm{ha}$ of dry mass during the seasons of 2018 and 2019. Dispersion analysis of data from the test of collecting dry mass of Sudan grazing grass showed sufficient accuracy in estimating the performance of the total population for 2018 and 2019. If Student criterion $=4.3$, the differences between arithmetic mean of the different levels are significant (Figure 4).

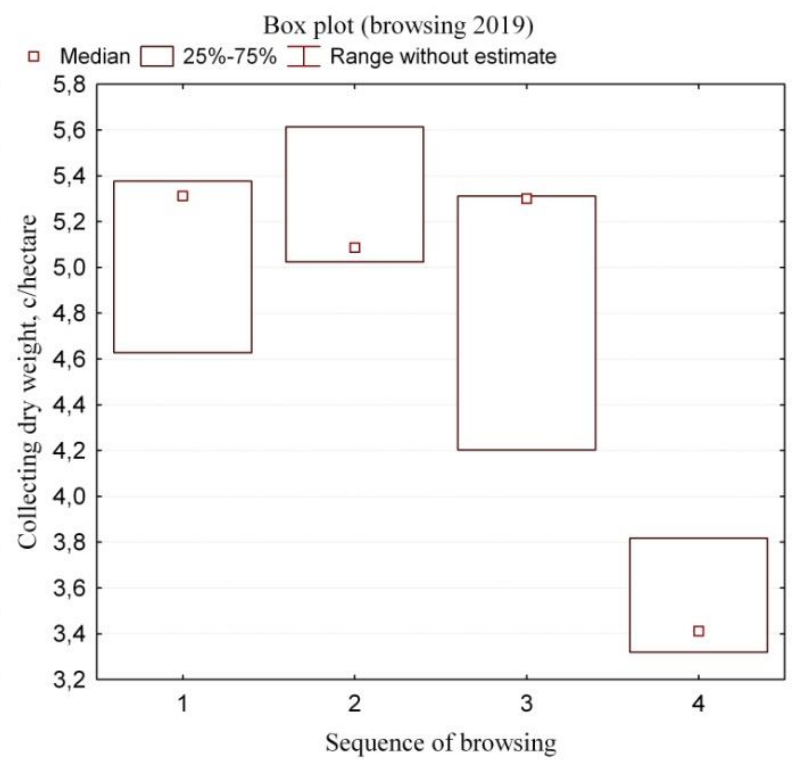

Figure 4. Productivity of Sudan grass under pasture mode used in 2018, 2019, c//ha

In the studies, the use of Sudan grass in grazing mode of use was also assessed by nutritional value and energy value. Analysis data show, on average, over 2 years of research, that Sudan grass, when used in grazing mode, provided a sufficient level of feed mass with satisfactory feed and energy merits. The yield of feed units, digestable protein and exchange energy was high in browsings 1 and 2. In the future, there was a decrease in the collection of nutritional and energy values. In total, for 4 browsings, Sudan grass on average for 2018, 2019 provided the collection of feed units $14.77 \mathrm{c} / \mathrm{ha}$, digestable protein 1.75 c/ha, with the yield of exchange energy $17.64 \mathrm{GJ} / \mathrm{ha}$. Supply of protein is $118.5 \mathrm{~g}$.

\section{CONCLUSION}

For the conditions of dry-steppe zone of West Kazakhstan, the most optimal sowing terms of Sudan grass for fodder purposes is in earlier periods at soil temperature at seed filling depth $8-10^{\circ} \mathrm{C}$. At early sowing time, Sudan grass uses resources more efficiently, thus differing in plant height, number of scions on plants, leaf area and decency. As a result, at early sowing period in dry steppe zone, Sudan grass forms a higher dry mass harvest, differing from later sowing by feed value as well.

The most optimal period of harvesting Sudan grass in the zone of dry steppes of West Kazakhstan is in the 
blooming period. When harvesting in earlier phases before and at the beginning of heading phase, biometric indicators decrease, which affects productivity and fodder value of Sudan grass.

In the area of dry steppes, it is advisable to use Sudan grass in grazing mode for uninterrupted provision of rural and household animals with full-fledged fodders.

\section{ACKNOWLEDGMENTS}

The work was carried out within the framework of the program of grant financing of the Science Committee of the Ministry of Education and Science of the Republic of Kazakhstan on the project AP05130172 "Development of adaptive technologies for the cultivation of fodder and oilseeds in relation to the conditions of West Kazakhstan".

\section{LITERATURE CITED}

Amaducci, S. and M. Colauzzi. 2016. Effect of irrigation and nitrogen fertilization on the production of biogas from maize and sorghum in a water limited environment. European Journal of Agronomy. 76:54-65.

Andreev, N.G. 1989. Meadow and field fodder production. M:492-495.

Basaran U., Dogrusor C.M., E. Gulumser and H. Mut. 2017. Hay Yield and quality of intercropped sorghum-sudan grass hybrid and legumes with different seed ratio. Turk J. Field Crops. 22(1):47-53 DOI: 10.17557/tjfc.301834.

Blanco, A. 2016. Multidisciplinary study of chemical and biological factors related to $\mathrm{Pb}$ accumulation in sorghum crops grown in contaminated soils and their toxicological implications. Journal of Geochemical Exploration.166:1826.

Bondarenko, M.G. and V.I. Kopyrin. 1985. Optimal terms of Sudan grass sowing for feed. Bulletin of Agricultural Science of Kazakhstan. 12:38-39.

Clark, A. 2007. Managing cover crops profi tably. SARE Outreach: 240-244.

Cole, C.A., Kaiser, A.G., J.W. Piltz and S Harden. 1996. An evaluation of sorghums for silage production in northern New South Wales. Proceedings of the 3rd Australian Sorghum Conference, Tamworth, NSW. 93:127-139.

Fribourg, H.A. 1995. Summer annual grasses. Forages. I:463472 .

Grigoriev, V.I. 1963. Cultivation of Sudan grass under the changed light mode. Research on plant physiology and biochemistry. 43:25-27.

Habyarimana, E., Bonardi, P., Laureti, D., di Bari, V., S. Cosentino and C. Lorenzoni. 2004. Multilocational valuation of biomass sorghum hybrids under two stand densities and variable water supply in Italy. Ind. Crops Prod. 20:3-9.

Kapustin, S.I. 2019. FSAOU. North Caucasus Federal University. 1:50-55

Kolomiec, N.Y., S.I Gorpinichenko and G.M. Yermolina. 1999. Stepniachka grade of Sudan grass. Corn and sorghum. 5:1718.
Kshnyakin, W.A. and Y.U. Zozulin. 1984. Impact of sowing timing on Sudan grass yield in North Kulunda. Novosibirsk:138-144.

Lukmanova, F.H. 2019. Bashkortostan SRIA.3:20-25.

McIntosh, D.W. 2016. Forage harvest timing impact on biomass quality from native warm-season grass mixtures. Agronomy Journal. 108:1524-1530.

Nasiyev B.N, Zhanatalapov N.Zh, A.N. Yessenguzhina and R. Yeleshev. 2019. The use of sudan grass for the production of green fodder, hay and haylage in Western Kazakhstan. Ecology, Environment and Conservation. 25(2):295-302.

Nazli, R.I., Inal, A., V. Kusvuran and Tansi. 2014. Effects of different organic materials on forage production from sorghum x. sudangrass hybrid (Sorghum bicolor x Sorghum bicolor var. sudanense). Turk J. of Agricultural and Natural Sci. Special Issue: 2:2075-2082.

Nichiporovich, A.A. 1961. Photosynthetic plant activity in crops. M:50-85.

Novoselov, Yu.K., Kharkov, G.D. and N.S. Shevtsova. 1987. Methodological instructions conducting field experiments with feed crops. Moscow, All-Russian Research Institute of Feed named after V.R. Williams: 49-55.

Novoselov, Yu.K., Shpakov, A.S., Yartieva, J.A., Grigoriev, N.G. and G.A. Dedaev. 1989. Methodological recommendations on bioenergetic assessment of crop rotations and technologies for growing fodder cultures. Moscow, All-Russian Research Institute of Feed named after V.R. Williams: 50-55.

Oten, M. 2017. The Effects of different sowing time and harvesting height on hydrocyanic acid content in some silage sorghum (Sorghum bicolor L.) varieties. Turk J. Field Crops. 22(2):211-217. DOI: 10.17557/tjfc.356224.

Puchkov, K.H. 1974. Features of Sudan grass development in pure form and in mixture with corn under irrigation conditions. Biological foundations of crop production. 54:55-59.

Sarrantonio, M. 1994. Northeast cover crop handbook. RodaleInstitute. 2:35-45.

Shatilov, I.S., Movsisyants, A.P. and I.A. Dranenko. 1981. Sudan grass. Moscow, Kolos: 52- 60.

Sliwinski, B. and F. Brzóska. 2008. Wykorzystanie kiszonek z sorgo w żywieniu krów mlecznych. Problemy agrotechniki oraz wykorzystania kukurydzy i sorgo. UP Poznań:263266.

Spaar, D. and D. Schuhmann. 2000. Die nat Orlichen Grund Jagen der Pflanzen-produktion in den Landern der GUS und des Baltikums. Buchedition Agrimedia Spithal. 620-628.

Tyutyunnikov, A.I. 1973. One-year fodder herbs. M:45-72.

Uzun, F.S., Ugur and M. Sulak M. 2009. Yield, nutritional and chemical properties of some sorghum x sudangrass hybrids (Sorghum bicolor (L.) Moench $\mathrm{x}$ Sorghum sudanense Stapf.). Journal of Animal and Veterinary Advances. 8:16021608.

Zavarzin, A.I., G.I. Kostina and I.V. Mahrov. 2002. World collection source of raw material for the selection of Sudan grass. Corn and sorghum. 6:20-21.

Zherukov, B.H., K.G. Magomedov and M.K. Magomedov. 2006. Terms of Sudan grass sowing. Farming. 2:45-46.

Zhuchenko, A.A. 1990. Adaptive Crop Production. M:350-355. 